\title{
Structural Analysis and Design of an Auditorium using Extended-3D Analysis of Building System
}

\author{
Ashwini Mareena Sam ${ }^{1}$, Devika J S ${ }^{2}$, Panchami P S ${ }^{3}$, Muhammad Salih $\mathrm{N}^{4}$, Rajeev Kumar $\mathrm{P}^{5 *}$ \\ $1,2,3,4$ IV yr BTech students; ${ }^{5}$ Professor \\ Department of Civil Engineering \\ Musaliar College of Engineering \& Technology, Pathanamthitta, Kerala
}

\begin{abstract}
This technical paper highlights the project work pertaining to the structural analysis and design of a multipurpose auditorium using a computer software, Extended3D Analysis of building System, abbreviated as $E T A B S^{\circledR}$. Shape of the auditorium was linear (rectangular). This includes planning, analysis of loads and designing of structural elements based on different loading conditions. Planning of acoustic and vision point of view were taken from National Building Code, and the limit state method of collapse using respective IS codes. AutoCAD ${ }^{\circledR}$ was used for drawing plan, elevation and section of auditorium. Design and analysis were done manually and the results were verified using ETABS ${ }^{\circledR}$. For completeness a cost estimation was also performed. Such a work would enable the economic design of an auditorium.
\end{abstract}

Keywords - Structural analysis; design, ETABS ${ }^{\circledR}, A u t o C A D^{\circledR}$, auditorium, cost estimation

\section{INTRODUCTION}

An auditorium is a multipurpose facility where a room built to enable an audience to hear and watch performances. For movie theatres, the number of auditoria (or auditoriums) is expressed as the number of screens. Auditoria can be found in entertainment venues, community halls, and theatres, and may be used for rehearsal, presentation, performing arts productions, or as a learning space. Seating arrangements in an auditorium seating layout (or assembly space) are either be identified as "multiple-aisle" or "continental." These terms are commonly found in design standards manuals, building codes, and similar architectural reference documents. Each size is unique, with specific guidelines governing row size, row spacing, and exit ways. Basically, a multiple-aisle arrangement will have a maximum of 14-16 chairs per row with access to an aisle-way at both ends. In a continental arrangement, all seats are located in a central section. Here the maximum quantity of chairs per row can greatly exceed the limits established in a multiple-aisle arrangement. In order to compensate for the greater length of rows allowed, building codes will require wider row spacing, wider aisles, and strategically located exit doors. Although it would seem like more space is called for, a continental seating plan is often not any less efficient than a multiple-aisle arrangement. In fact, if it is carefully planned, a continental arrangement can frequently accommodate more seating within the same space [1].

Many researchers have conducted works in this area [2][5]. Objective of this paper is to perform the structural analysis and design of a multipurpose auditorium for a seating capacity of 1000 audience, at Pathanapuram municipality, Kerala state. In this paper details of the analysis and design of an auditorium done by the software package called as ETABS $^{\circledR}$. ETABS $^{\circledR}$ is the abbreviation of "Extended 3D Analysis of Building System" [6]. For completeness, a cost estimation for construction is also performed. It is thought that such a study would help to perform an economical and environment friendly design and construction of an auditorium at this location.

\section{LOCATION DETAILS OF THE SITE}

The proposed site is at Pathanapuram municipality, Pathanamthitta district, Kerala state. Figure 1 shows the proposed site and Table 1 gives the details of the proposed auditorium:

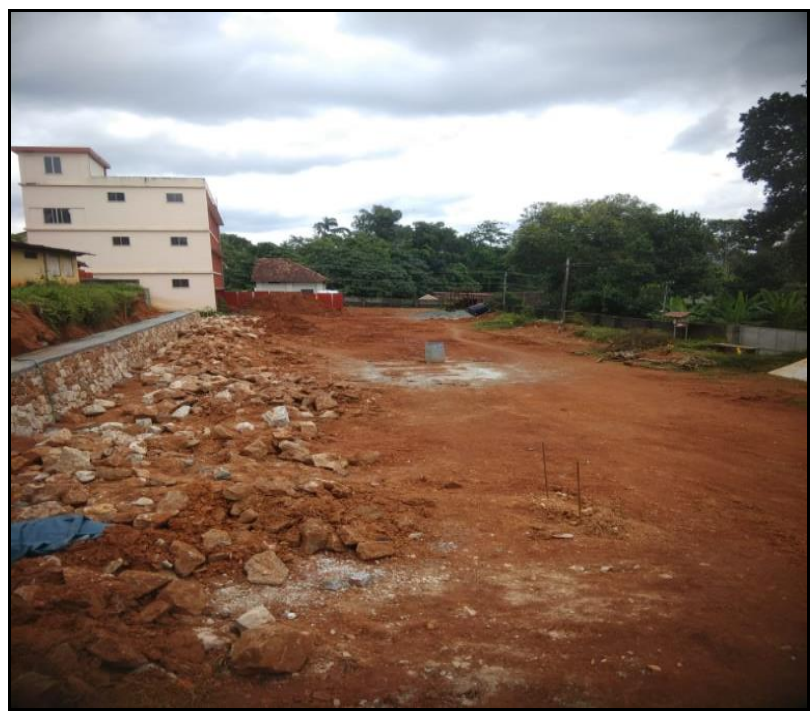

Fig. 1. Proposed site in Pathanapuram, Kerala state

TABLE I. DETAILS OF PROPOSED AUDITORIUM

\begin{tabular}{|c|c|}
\hline District/State & Pathanamthitta/Kerala \\
\hline Municipality/Taluk & Pathanapuram \\
\hline Type of auditorium & Multipurpose \\
\hline Type of soil in the site & Lateritic soil \\
\hline Type of structure & RCC/steel \\
\hline Estimated capacity & 1000 \\
\hline Estimated Area & 10764 sq. ft. \\
\hline Estimated Area of Auditorium & $8000-10000$ sq. ft \\
\hline
\end{tabular}

\section{ANALYSIS AND DESIGN OF AUDITORIUM}

\section{A: PLANNING OF AUDITORIUM}

A number of standard codes approved by Indian Standard institutions has specified the following minimum requirements for the construction of the auditoriums: 


\section{FRONT AND REAR OPEN SPACES:}

No person shall erect a building unless it is set back at least $6 \mathrm{~m}$ from the regular line of the street or from the street if no such regular line exists.

\section{PLAN AREA:}

Plan area of the building is to be fixed at an occupant load of range 0.6 to $0.9 \mathrm{~m}^{2} /$ member.

Drawings were done using AutoCAD ${ }^{\circledR}$. Details of the stepby-step procedure can be obtained from [7]. Site plan, front elevation, side elevation, cross-section and plan are shown in Figures 2 to 6. Different components of the auditorium are given in Table 2.

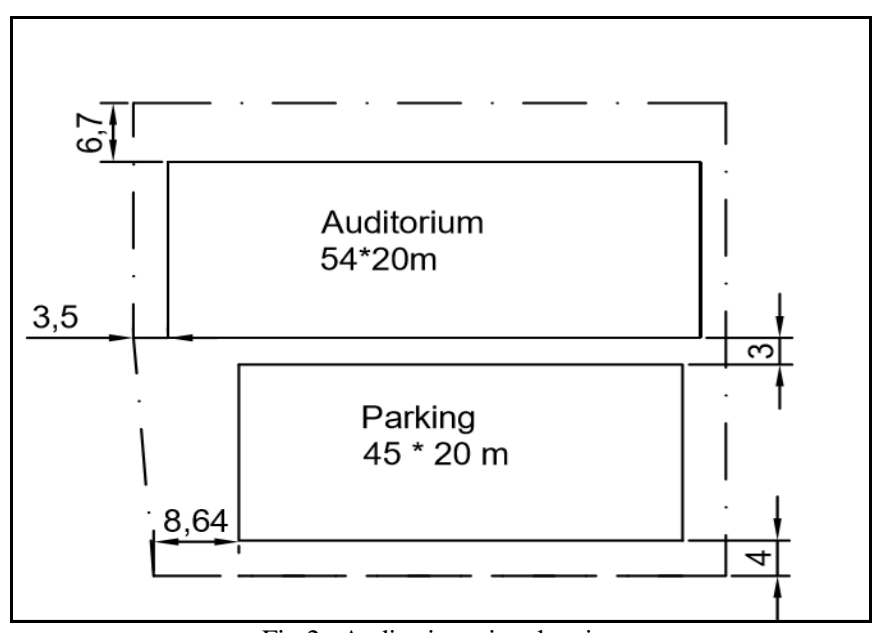

Fig 2. Auditorium site planning

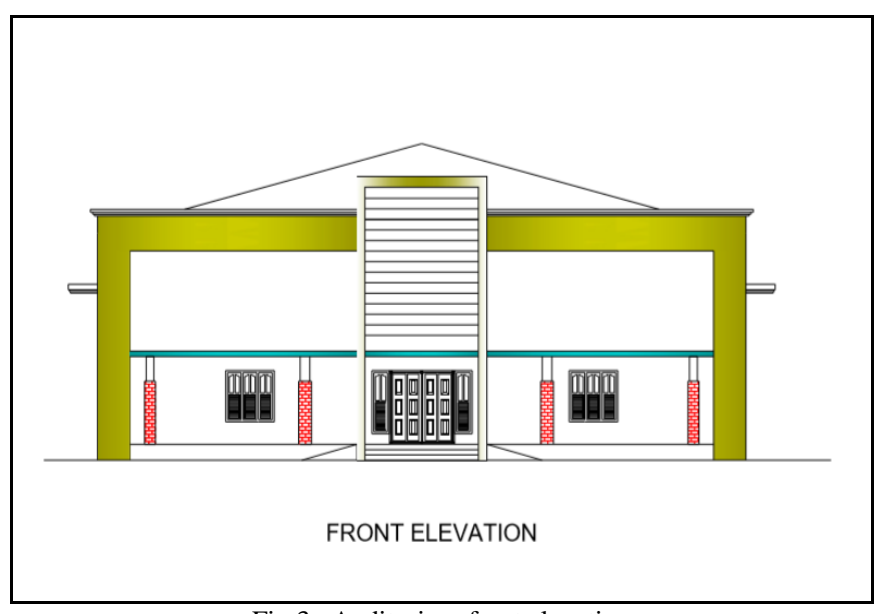

Fig 3. Auditorium front elevation

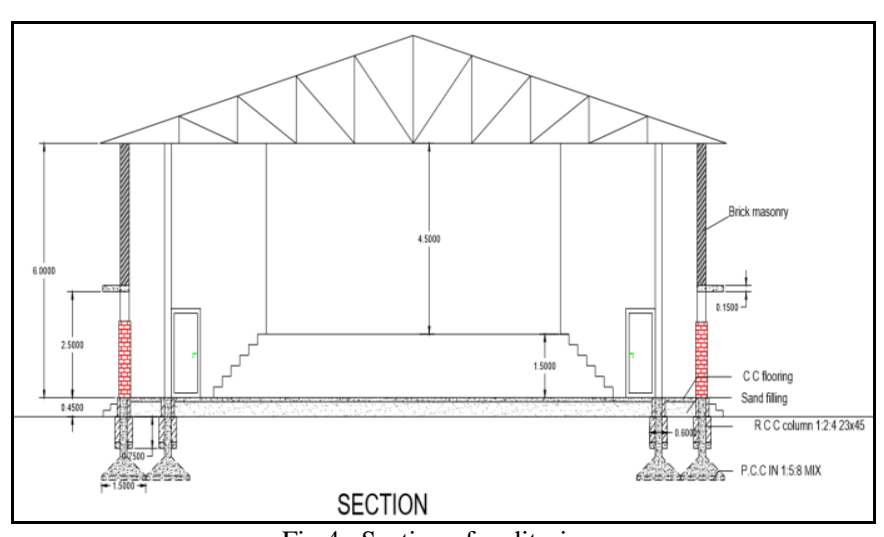

Fig 4. Section of auditorium

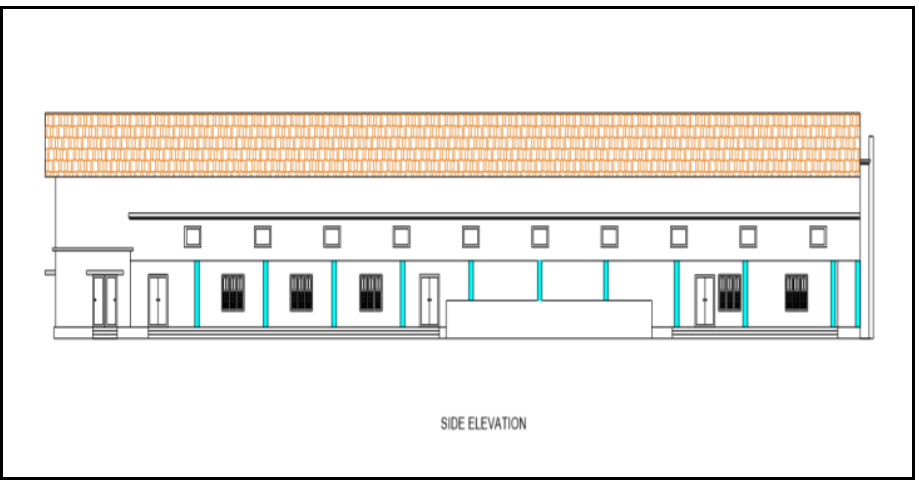

Fig 5. Auditorium side elevation

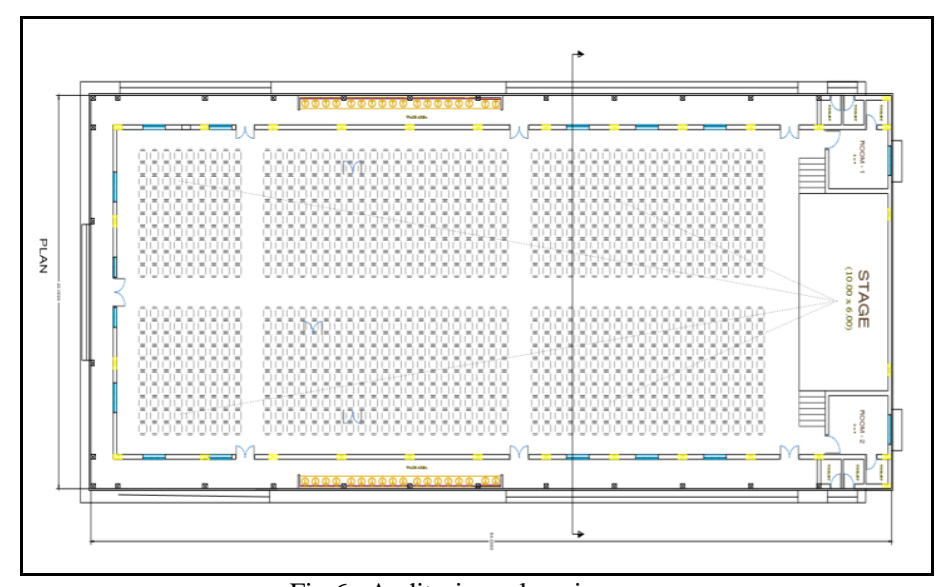

Fig 6. Auditorium plan view

\section{B: ETABS ANALYSIS}

As discussed in the above sections, structural analysis was done using ETABS $^{\circledR}$. Different steps involved in the process is shown below.

TABLE II: COMPONENTS OF THE AUDITORIUM

\begin{tabular}{|l|l|l|l|}
\hline Components & Standard Sizes & Size Provided & $\begin{array}{l}\text { Quantities } \\
\text { Provide }\end{array}$ \\
\hline Side Entrance & $1.5-3 \mathrm{~m}$ & $1.5 \mathrm{~m}$ & 6 \\
\hline Main entrance & $1.5 \mathrm{~m}$ & $1.5 \mathrm{~m}$ & 1 \\
\hline $\begin{array}{l}\text { Total seats at } \\
\text { ground floor }\end{array}$ & $0.45-0.65 \mathrm{~m}$ & $0.5 \mathrm{~m} \times 0.46 \mathrm{~m}$ & 1000 \\
\hline $\begin{array}{l}\text { no of seats per } \\
\text { row }\end{array}$ & $0.45-0.65 \mathrm{~m}$ & $0.5 \mathrm{~m} \times 0.46 \mathrm{~m}$ & 10 \\
\hline $\begin{array}{l}\text { no of seats per } \\
\text { Coloumn }\end{array}$ & $0.45-0.65 \mathrm{~m}$ & $0.5 \mathrm{~m} \times 0.46 \mathrm{~m}$ & 50 \\
\hline $\begin{array}{l}\text { Steps provided at } \\
\text { entrance }\end{array}$ & As per planning & $3.5 \mathrm{~m}$ & 3 \\
\hline $\begin{array}{l}\text { Steps guiding to } \\
\text { stage }\end{array}$ & As per planning & $1.7 \mathrm{~m}$ & $\begin{array}{l}\text { at each } \\
\text { side }\end{array}$ \\
\hline $\begin{array}{l}\text { Distance between } \\
\text { two chairs for } \\
\text { circulation }\end{array}$ & At least 0.85 $\mathrm{m}$ & $0.87 \mathrm{~m}$ & \\
\hline Changing room & As per planning & $3 \times 4 \mathrm{~m}$ & 2 \\
\hline Gents Toilet & As per planning & $1.5 \times 1.5 \mathrm{~m}$ & 3 \\
\hline Ladies Toilet & As per planning & $1.5 \times 1.5 \mathrm{~m}$ & 3 \\
\hline
\end{tabular}

The structure created in the ETABS ${ }^{\circledR}$ is shown in Figure 7. Inbuilt algorithms in the software do the analysis of the structure and give the output files. Figures 8 and 9 show the loads applied on the structure and the output of final analysis output respectively. From the output files different standard sections can be obtained and it is used for the construction. 


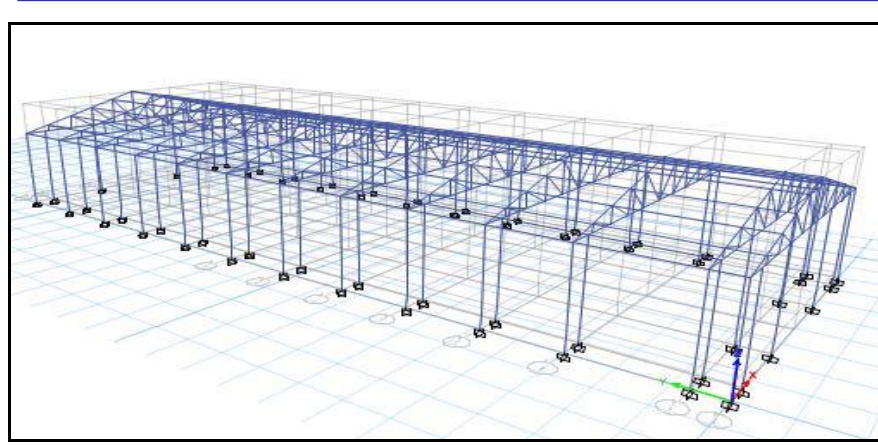

Fig 7. Structure created in ETABS

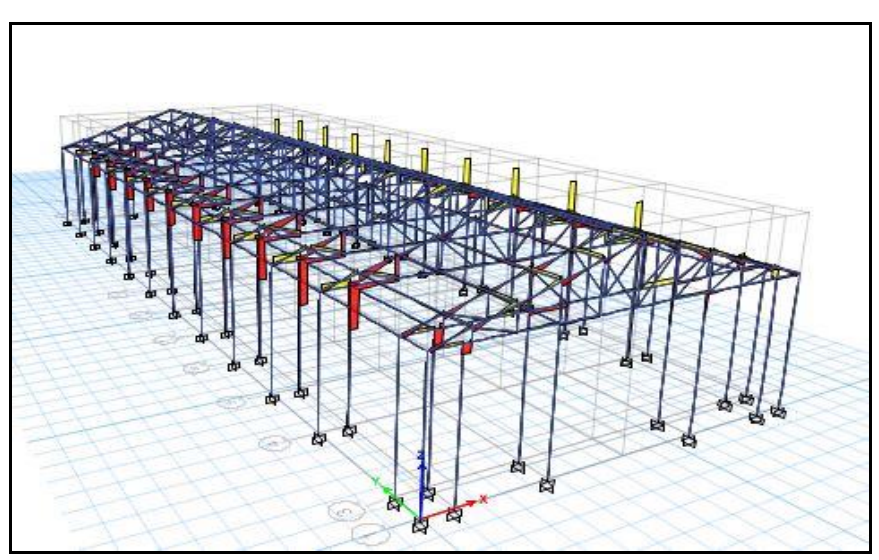

Fig 8. Loads applied on the structure

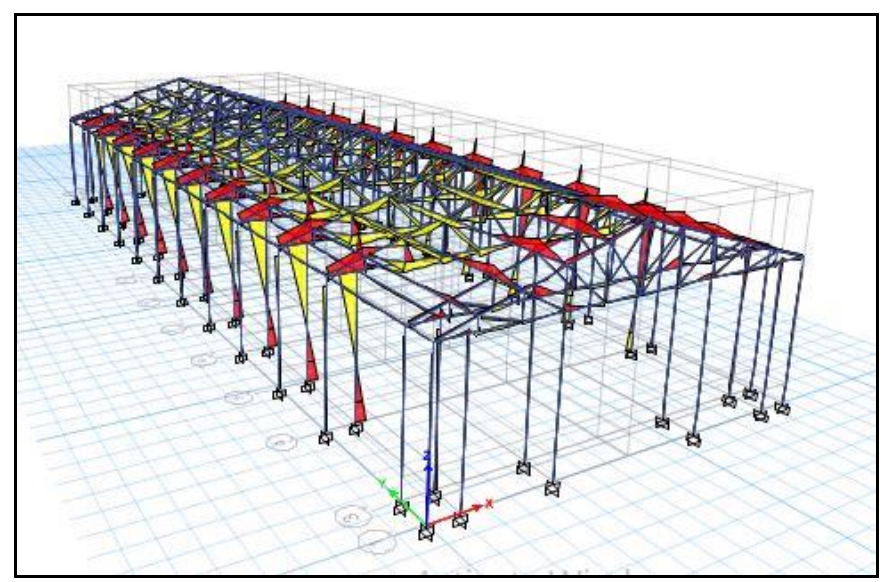

Fig 9. Output of analysis of the structure

\section{CONCLUDING REMARKS}

This work highlighted the analysis and design of a multipurpose auditorium at Pathanapuram municipality, Kerala state using ETABS ${ }^{\circledR}$ software. Preliminary drawings were done using AutoCAD ${ }^{\circledR}$. For completeness, a cost estimation for the construction was also carried out and the estimated cost was found as Rs 1,22,00000/-.

\section{REFERENCES}

[1] National Building Code of India (2018), Bureu of Indian Standards, New Delhi.

[2] Ch. Pratyusha et al(2017) PLANNING, ANALYSIS AND DESIGN OF AUDITORIUM, International Journal For Technological Research In Engineering Volume 4, Issue 12

[3] Bhoite et al(2017) Design Of College Auditorium For PES College Of Engineering, Phaltan, International Journal of Informative \& Futuristic Research, 7 ,6851-6858.

[4] Sri Priya et al(2018) Design of an Auditorium Building, International Journal of Innovative Research in Science, Engineering and Technology, Vol. 7, Issue 4.

[5] Shivam Asawa et al (2017) Structural Design of Concrete Structure Using E-Tabs IOSR Journal of Mechanical and Civil Engineering, Volume 14, Issue 1 PP 49-51

[6] ETABS v16 (2018) Computures and structures Inc. USA

[7] AutoCAD (2018) AutoDESK Inc, USA.

[8] Ramamrutham S (2016), Design of RC Structures. S Dhanpat Rai publications, New Delhi

[9] Norris C.H. and Wilbur J (1991), Elementary Structure Analysis, 10th Edition, McGraw-Hill company limited, New York.

[10] IS: 875 (1987), Part III - Code of Practice for Design Wind Loads for buildings. Bureu of Indian Standards, New Delhi.

[11] IS 456:2000 Plain Concrete - Code of practice, Bureu of Indian Standards, New Delhi. 